\title{
Extraction and Fractionation of Phospholipids from the Waste of Jambal Siam (Pangasius Hypophtalmus) Processing
}

\author{
Mirna Ilza* and Dian Iriani \\ Faculty of Fisheries and Marine Science Universitas Riau, Indonesia \\ mirna.ilza@yahoo.co.id,dhian.iriani@gmail.com
}

\begin{abstract}
This research aimed to extract and fractionate the waste of Jambal Siam (Pangasius hypophtalmus) fish processing with acetone and ethanol and also the characteristics of fatty acid of phospholipids fraction was yielded. The fractination process with acetone and ethanol estimated that the fractination of Phospholipids with different composition of fatty acid could yielded. The result of this research indicate that the highest saturated fatty acid contents on waste processing jambal siam was palmitate acid which estimated predominante in phosphatidylglycerol (PG), phosphatidic (PA), and kardiolipin (DPG) forming. The highest of unsaturated fatty acid contents was oleat acid which estimated predominate in phosphatidylinositol (PI), phosphatidyl ethanolamine (PE), and phosphatidylcholine (PC) forming.
\end{abstract}

Keywords: acetone, ethanol, Pangasius hypophtalmus, waste

\section{Introduction}

\subsection{Background}

Jambal siam (Pangasius hypophtalmus) fish or better known by the public as catfish that live in pond and cage, is one of many farmed fish are cultivated by the people in Riau province, especially in Kampar regency. According to [1] the production of farming jambal siam fish in 2008 reached 13.206 tons, this production increased from 2007 with total production of 6.391 tons, and in 2006 the total production of 3.394 tons. In 2011 Kampar regency can increase the production of jambal siam fish about 50 tons per day, in 2015 the production has reached 100 tons per day. This jambal siam fish is a fish that many consumers preferred in fresh condition and has a high fat content relatively.

Based on these data, it can be seen that the farming of jambal siam fish in Riau province continues to increase every year so that it can lead to an abundance production of jambal siam fish. One effort to overcome the abundance of production and saturation of the consumer to fresh jambal siam fish is by doing business of fishery products processing. Jambal siam fish processing conventionally that many people do is the smoked fish and salted fish, while non conventional has not been done. Processing will produce waste in the form of fish entrails are intended to be discarded and not used. In addition to waste from processing, waste fish entrails jambal siam also came from the rest of the cuts of fish for household consumption and industrial restaurants in Pekanbaru and surrounding areas. The relatively large amount of waste, especially when coupled with the waste of other fish species that are also widely cultivated in Kampar district particularly and Riau Province generally.

Utilization of fish jambal conjoined so far is limited only as food. This gives the consequences of the economic value of fish jambal siam relatively low. To increase the economic value of fish jambal siam necessary research leading to production of non-food products of superior, one of which is the raw material drug industry. These opportunities 
can be opened ranging from belly fat fish waste jambal siam, suspected to contain polyunsaturated fatty acids are relatively high. Several previous studies have shown that some parts, the abdominal fat and the liver often discarded for some reason when the fish are prepared for consumption, in terms of nutritional value and health effects are good especially because the content of EPA and DHA. Valuable fish oil can be obtained from fish waste. Fish waste is usually composed of a head, bones and tissue engaging member that is rich in fat and protein. Since so many health benefits of fish oil for the potential jambal siam fish waste needs to be improved for the source of local fish oils have the opportunity to be used as raw material for the pharmaceutical industry.

Waste entrails jambal siam fish consists of the digestive tract, fat, liver, and other organs. In the belly of the jambal siam fish there are about $1-2 \%$ fat pale yellow colored and solid form. These fats are classified as lipids which is located near the digestive tract jambal siam fish. Fats from jambal siam fish will be more in line with the expanding body size of fish. In addition, the fat content jambal siam fish will also increase the fish mature gonad.

Phospholipid (glycerophospholipid) a class of lipid compounds and is part of the membrane of living cells. Part of fat that is important enough to be in the cell is a phospholipid that is fat-containing phosphor. Lecithin is an especially important phospholipid found in cell membranes. Phospholipid consist of four components: fatty acids, a phosphate group, an alcohol containing nitrogen, and a framework. Phospholipid have a framework of glycerol and 2 acyl groups. In the third position of the glycerol frame is occupied by a phosphate group to the amino alcohol.

Food materials like fish oil and egg yolk included several classes of phospholipids: phosphatidylcholine (PC), phosphatidylethanolamine (PE), sphingomyelin (SM), lysophosphatidylcholine (LPC), lysophosphatidylcholine (LPE), and phosphatidylglycerol (PG). The most important phospholipid fractions of fish oil are PC and PE. Phospholipids are analyzed by chromatographic techniques, such as the following: thin layer chromatography (TLC), gas chromatography (GC).

The demand for various types of phospholipid is current constantly increasing because of its use in the industry continues to increase. Phospholipid are used for food product, medicinal formula, stabilizer, lubricant, cosmetic, pharmaceutical ingredient, and as an emulsifier. Synthetic phospholipid can be used for food and medicine, but now the interest of consumers switching to phospholipid from natural material.

Phospholipids have functional properties to health, market demand often require phospholipids fatty acids such as omega 3 changes in fatty acid composition can be made through the hydrolysis reaction [2].

Omega-3 fatty acids in phospholipid structure is more stable to oxidation than in the form of free fatty acids or triglycerides [3]. Phospholipids containing omega-3 fatty acids can be obtained from fish. In jambal Siamese fish belly fat containing phospholipids are the rest of the processing is not used. Therefore it should be used to meet consumer needs for phospholipids containing omega 3. Gladkowski [4] revealed that changes the molecular structure of phospholipids is intended to obtain properties suitable phospholipids different functional properties of phospholipids origin. The new Fosfolipd with the resulting chemical properties can be obtained by changing the type of fatty acids in the phospholipids with an organic solvent.

Riau province has potential phospholipid sources at its optimum, ie phospholipid from fish processing waste jambal siam. Most phospholipids are still in the fish processing waste jambal siam. Assessment phospholipid from fish processing waste jambal siam is important.

The fatty fish consists of various types of triglyceride is a molecule composed of glycerol and fatty acid [5], and triglyceride soluble in acetone, but insoluble lecithin polar compound $[6,7]$. For ease of handling highly viscous crude lecithin and to improve the 
dispersibility in water, the industry usually use acetone. Acetone extraction causes the phospholipid become concentrated thus increasing the level.

The egg yolk phospholipid extracted by using ethanol, followed by the extraction of acetone to remove fat from ethanol fraction $[8,3]$. In this study examines methods of extraction and fractionation of phospholipid from fish processing waste jambal siam with ethanol and acetone and characteristics phospholipid fraction produced. The process of fractionation with ethanol and acetone could be expected to produce a phospholipid fraction with different fatty acid composition.

\subsection{Formulation of the Problem}

Jambal siam fish processing into smoked fish and salted fish in Kampar regency produces waste in the form fish entrails are intended to be discarded and not used. The relatively large amount of waste, especially when coupled with the waste of other fish species that are also widely cultivated in Kampar regency especially and Riau Province generally.

Jambal siam fish processing waste consisting of the gastrointestinal tract, fat, liver, and other organs. In the belly of the jambal siam fish there are about $1-2 \%$ fat pale yellow colored and solid form. These fat are classified as lipid which is located near the fish digestive tract jambal conjoined. In the lipid contains phospholipid required by the food industry, medicine, pharmaceutical, and cosmetic.

Given the lack of research on the extraction and fractionation of fish processing waste jambal siam, therefore it is important to do research so that fish waste has added value. In addition, this study also important for those who need information about the extraction and fractionation of phospholipid jambal siam fish waste as well as meet the need of industrial to natural phospholipid.

\subsection{Research Purposes}

The purpose of this research was to extract and fractionate phospholipid from the waste jambal siam (Pangasius hypophtalmus) fish processing.

\section{Research Methods}

\subsection{Location}

This research was conducted at the Laboratory of Food Chemistry Department of Fishery Product Technology Faculty of Fisheries and Marine Sciences Universitas Riau, and the Integrated Laboratory of Bogor Agricultural Institute.

\subsection{Materials and Tools}

Raw materials used in this study was jambal siam fish waste (Figure 1). The fish waste derived from Kampar regency. The chemicals used were the standard mixture of fatty acid, methylenechloride, $\mathrm{NaOH}$, methanol, chloroform, ethanol, acetone, distilled water, and nitrogen gas. 


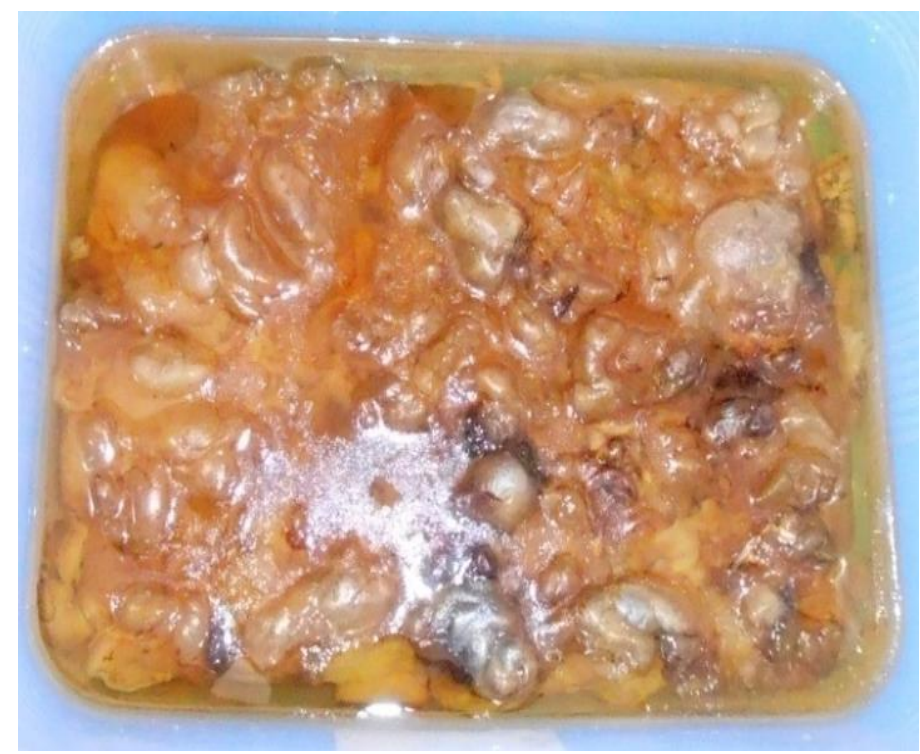

Figure 1. Jambal Siam Fish Waste

The equipment used was water bath shaker, gas chromatography, oven, UV lamp, glass tools, and a rotary evaporator. The study is primarily based on the extraction of total lipid, phospholipid separation of total lipid, phospholipid fractionation, and identify the constituent fatty acid.

\subsection{Research Procedure}

\subsubsection{Extraction of Fat Fish}

To determine the fat content of the fish was using Soxhlet method [9], with the following procedures:

- Samples were crushed (preferably dry and passing 40 mesh) and weighed as much as $50 \mathrm{~g}$ and put into a Soxhlet extraction tube in a paper lead.

- Cooling water flowed through the condenser.

- Test tube mounted on soxhlet distillation with diethyl ether solvent of $100 \mathrm{ml}$ for 5 hours. Then repeated until the unused sample weight of $400 \mathrm{~g}$ ( 8 repetitions).

- The second and subsequent $50 \mathrm{ml}$ diethyl ether was added to each sample repetitions.

- Diethyl ether containing extract fat that has been removed from the soxhlet and dried in an oven for 2 hours at a temperature of $60^{\circ} \mathrm{C}$.

- Then cooled in a desiccator for 30 minutes and weighed. Drying in the oven forwarded to constant weight. Heavy residue in the weighing bottle was expressed as the weight of fatty fish (Figure 2). 


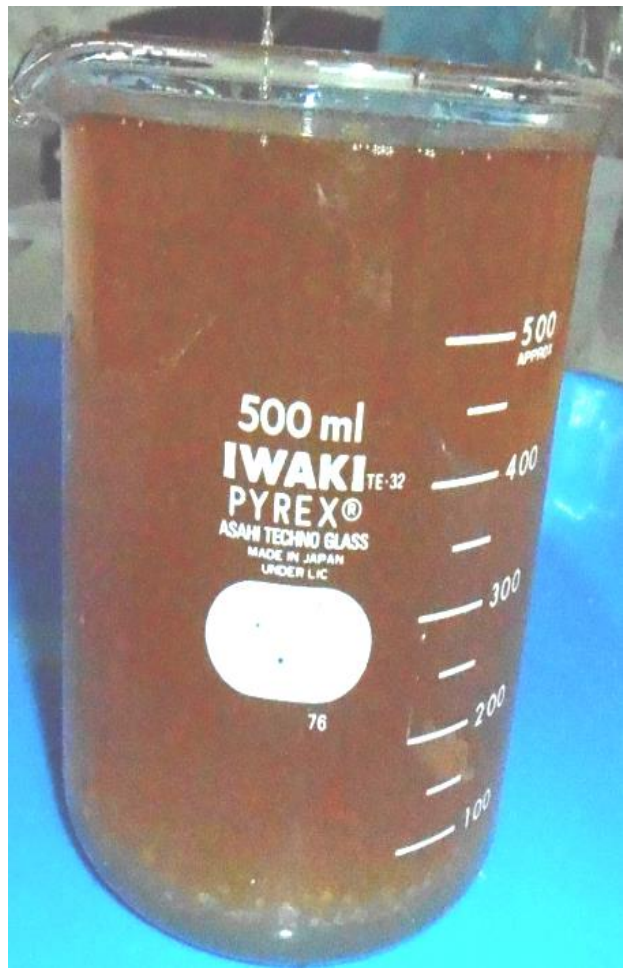

Figure 2. Fatty Fish

\subsubsection{Separation of Phospolipids Crude Extract of Total Lipid by Dissolution}

Total lipid obtained from the extraction process was extracted using chloroform [8]. A total of $10 \mathrm{~g}$ of total lipid extracted with $40 \mathrm{ml}$ of chloroform. A chloroform-soluble fraction and a non-polar lipid were separated by centrifugation at a speed of $5000 \mathrm{rpm}$ for 10 minutes. Insoluble fraction of a polar lipid and separated. Soluble fraction was dried using nitrogen/aeration and re-extracted using $30 \mathrm{ml}$ of chloroform, and then centrifuged to separate soluble and insoluble fraction.

Insoluble fraction of a polar lipid and mixed with the insoluble fraction from the first extraction. Furthermore chloroform insoluble fraction extracted by using $20 \mathrm{ml}$ of methanol to dissolve the polar phospholipid. Insoluble fraction was separated by centrifugation at $5000 \mathrm{rpm}$ for 10 minutes. Soluble fraction was dried to take solid which were phospholipid (Figure $3 \mathrm{a}, \mathrm{b}$ )

\subsubsection{Phospholipid Fractionation}

Extracted phospolipid was dissolved in ethanol and acetone. The first fractionation was done by using ethanol. Ethanol soluble fraction further fractionated using acetone.

Fractionation process was performed as follows: $5 \mathrm{~g}$ phospholipid crude dissolved in $20 \mathrm{ml}$ of ethanol, agitated for 60 minutes. Supernatant and the precipitate was separated by centrifugation at $5000 \mathrm{rpm}$ for 10 minutes. The residue was taken and an insoluble fraction of ethanol. Ethanol soluble fraction was taken by evaporating ethanol by spraying nitrogen gas/air.

Ethanol soluble fraction was taken partly for and partly characterized further fractionated by dissolving acetone (1: $4 \mathrm{w} / \mathrm{v})$ and agitated for 60 minutes. Acetone insoluble fraction was separated from the solution by centrifugation at $5000 \mathrm{rpm}$ for 10 minutes (Figure $4 \mathrm{a}, \mathrm{b}$ ).

Acetone soluble fraction was taken by evaporating acetone with nitrogen gas/air. The results of the four fractions obtained by fractionation of phospholipid that fraction insoluble ethanol, insoluble fraction of ethanol, ethanol and acetone soluble fraction, the 
fraction insoluble ethanol and acetone, and phospholipid without fractionation or crude phospholipid. Fractions are then identified the types of constituent fatty acid [8].

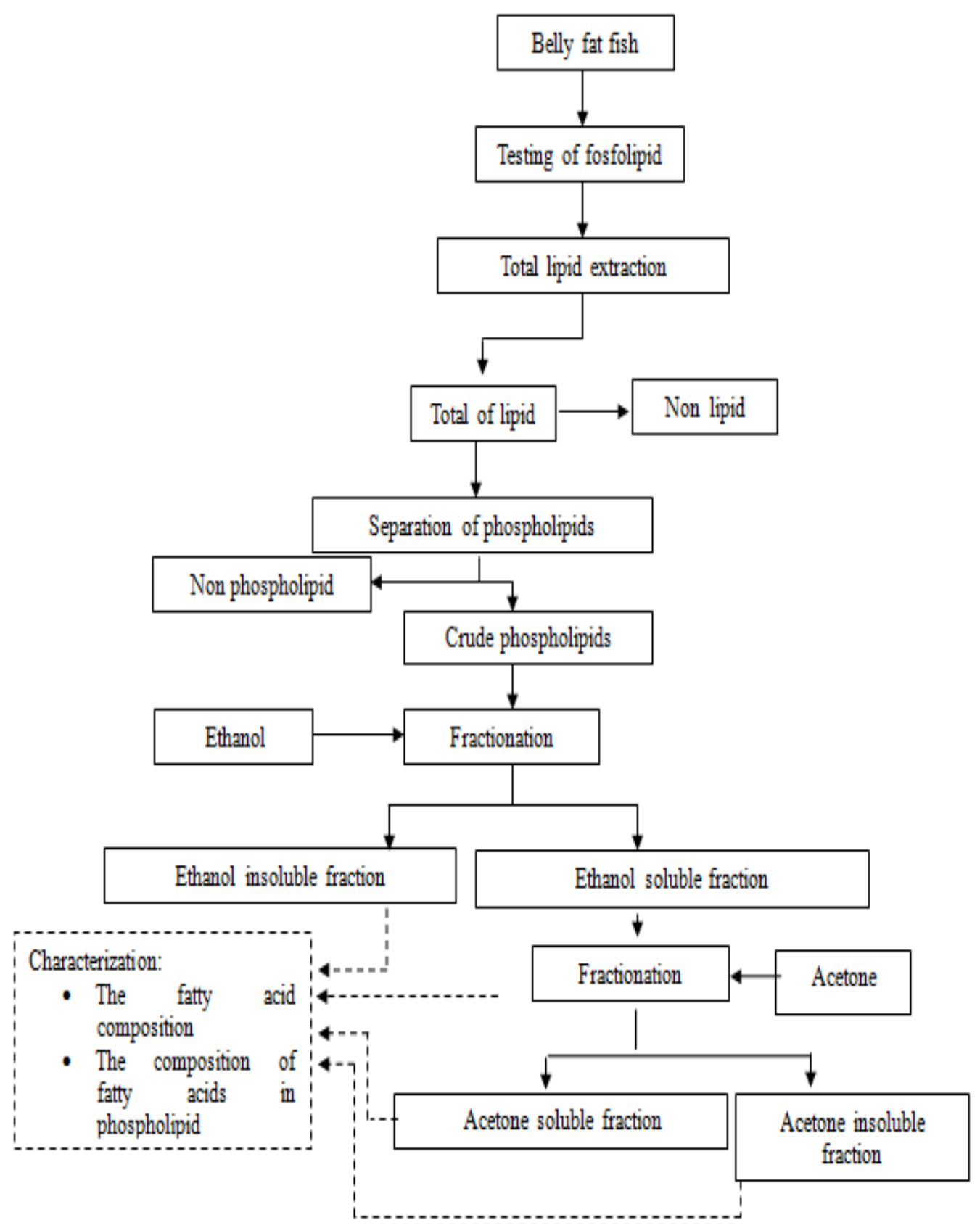

Figure 3 a. Total Lipid Extraction, Separation, and Fractionation of Phospholipids 


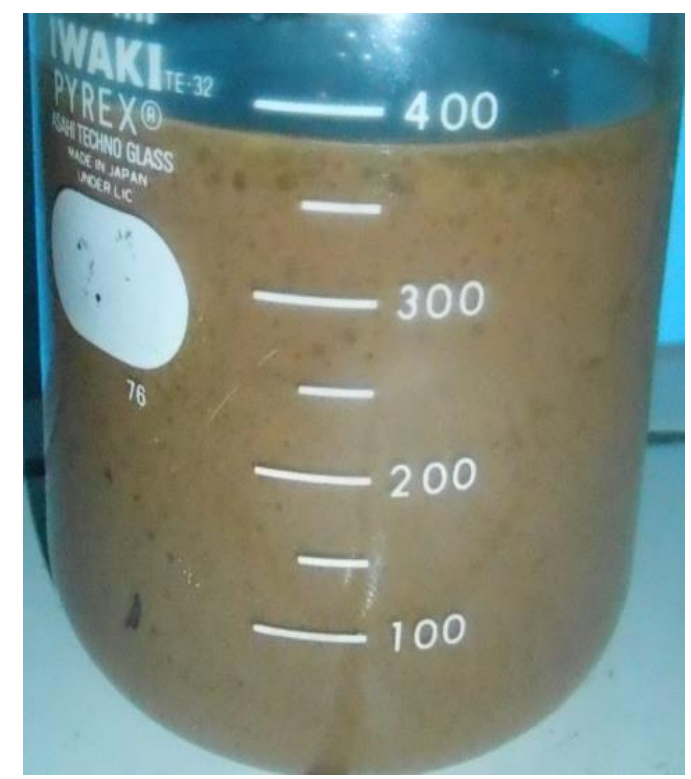

Figure 3 b. Phosfolipid

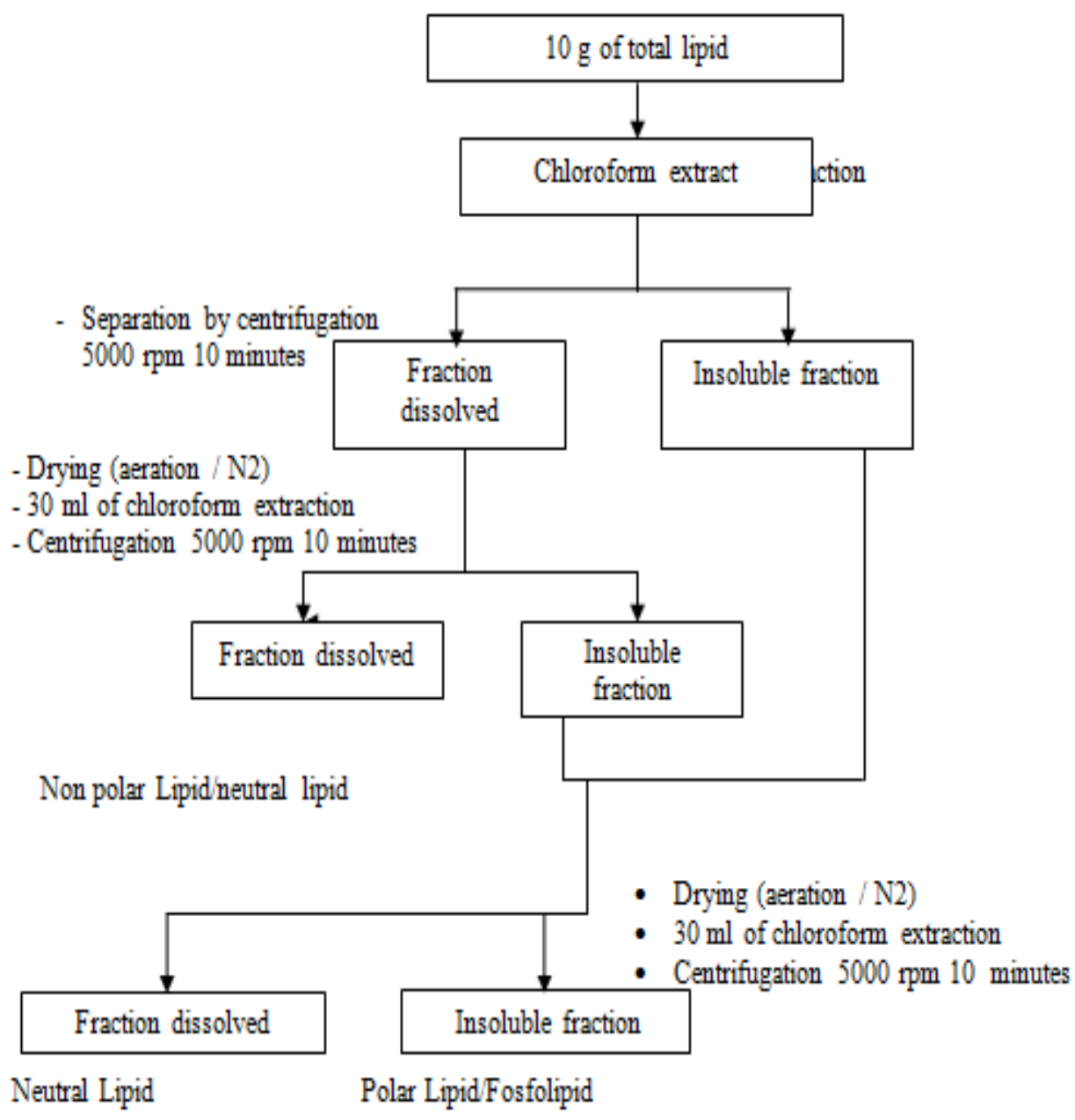

Figure 4 a. Phospholipids Separation of Total Lipids from the Solvent 


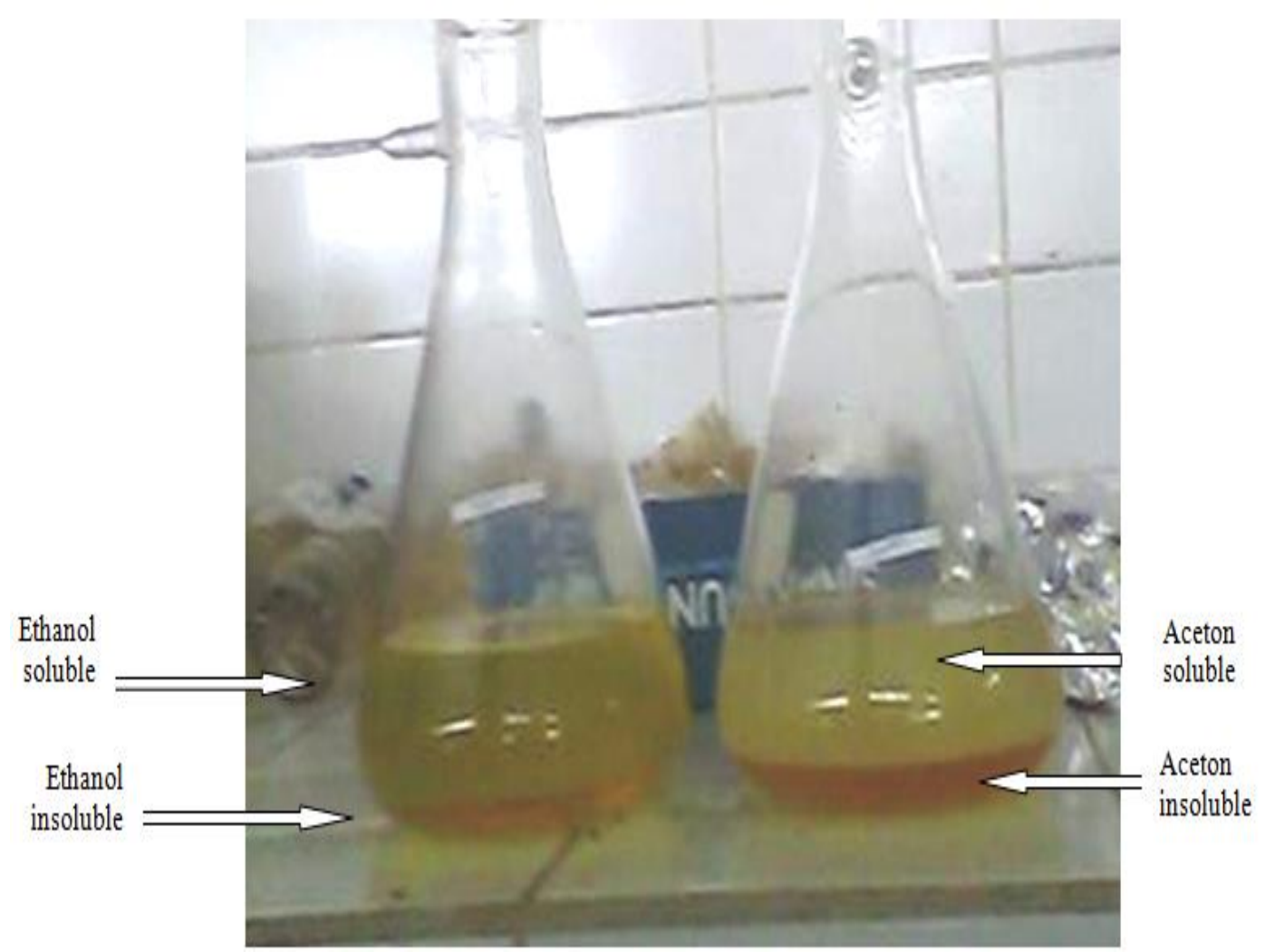

Figure 4 b. Ethanol Soluble Fraction and Insoluble Fraction Aceton Soluble Fraction and Insoluble Fraction

\subsubsection{Identify the Type of Fatty Acid in Crude Phospholipid and Phospholipid Fraction}

Identify the type of fatty acid of any phospholipid fraction carried by gas chromatography [10]. The identification was done by comparing the retention time of the standard mixture of fatty acid that was injected separately. Quantification was done based on the relative percentage.

\subsubsection{Data Analysis}

The data obtained were processed descriptively and presented in tabular form. Further data on fractionation and fatty acids contained in each fraction discussed using crude phospholipid fraction as a comparison.

\section{Results and Discussions}

\subsection{Saturated Fatty Acid (SAFA)}

The results of the analysis of saturated fatty acids (Saturated Fatty Acid /SAFA) using gas chromatography showed that saturated fatty acids were detected in each of the different phospholipid fraction amount. In each of the fractions can be detected as many as 11 kinds of saturated fatty acids to total saturated fatty acids $35.94 \%-44.27 \%$. 
Table 1. Saturated Fatty Acid Composition of Phospholipid Fraction

\begin{tabular}{|c|c|c|c|c|c|}
\hline \multirow[b]{2}{*}{ Fatty acid type } & \multicolumn{5}{|c|}{ Amount (\%) } \\
\hline & $\begin{array}{l}\text { Crude } \\
\text { fosfolipid }\end{array}$ & $\begin{array}{l}\text { Soluble } \\
\text { in ethanol }\end{array}$ & $\begin{array}{l}\text { Insoluble } \\
\text { in ethanol }\end{array}$ & $\begin{array}{l}\text { Soluble } \\
\text { In } \\
\text { aceton }\end{array}$ & $\begin{array}{l}\text { Insoluble } \\
\text { in } \\
\text { acetone }\end{array}$ \\
\hline Lauric acid, C12:0 & 1.94 & 1.26 & 1.50 & 118 & 1.30 \\
\hline Myristic acid, C14:0 & 4.51 & 3.83 & 4.07 & 3.75 & 3.87 \\
\hline $\begin{array}{l}\text { Pentadekanoat acid, } \\
\text { C15:0 }\end{array}$ & 1.99 & 1.31 & 1.55 & 1.23 & 1.35 \\
\hline Acid Palmitate, C16:0 & 18.83 & 18.15 & 18.37 & 1.07 & 18.19 \\
\hline $\begin{array}{l}\text { Heptadekanoat acid, } \\
\text { C17:0 }\end{array}$ & 2.02 & 1.34 & 1.58 & 1.26 & 1.38 \\
\hline Stearic acid, C18:0 & 5.26 & 4.53 & 4.82 & 4.50 & 4.62 \\
\hline Arakhidat acid, C20:0 & 2.08 & 1.40 & 1.64 & 1.32 & 1.44 \\
\hline $\begin{array}{l}\text { Heneikosanoat acid, } \\
\text { C21:0 }\end{array}$ & 1.88 & 1.20 & 1.44 & 1.12 & 1.24 \\
\hline Behenic acid, C22:0 & 1.93 & 1.27 & 1.51 & 1.19 & 1.31 \\
\hline Trikosanoat acid, C23:0 & 1.89 & 1.21 & 1.45 & 1.13 & 1.25 \\
\hline Lignoserat acid, C24:0 & 1.94 & 1.26 & 1.50 & 1.19 & 1.34 \\
\hline $\begin{array}{l}\text { Saturated Fatty Acid } \\
\text { Total }\end{array}$ & 44.27 & 36.76 & 39.43 & 35.94 & 37.29 \\
\hline
\end{tabular}

Highest amount of fatty acid was palmitic acid, i.e., on crude phospholipid $18.83 \%$, ethanol soluble phospholipid $18.15 \%$, phospholipid insoluble ethanol $18.37 \%$, acetone insoluble phospholipid $18.07 \%$, and phospholipid insoluble acetone $18.19 \%$. For more details, the results of the analysis can be seen in Table 1 .

The palmitic acid dominates the formation phospatidilgliserol (PG), phosphatidic acid (PA), and cardiolipin (DPG). Differences in the fatty acid composition of each fraction of phospholipids was expected to affect the functional properties of phospholipids such as emulsification ability [8].

\subsection{Monounsaturated Fatty Acids (MUFA)}

Monounsaturated fatty acids/ MUFA) fractionation of phospholipids were analyzed using gas chromatography was different amount. The type and amount of fatty acids contained in each fraction are shown in Table 2. 
Table 2. Mono Unsaturated Fatty Acids Composition of Phospholipid Fraction

\begin{tabular}{lccccc}
\hline & \multicolumn{5}{c}{ Amount (\%) } \\
\cline { 2 - 6 } \multicolumn{1}{c}{ Fatty acid type } & $\begin{array}{l}\text { Crude } \\
\text { Fosfolipid }\end{array}$ & $\begin{array}{l}\text { Soluble } \\
\text { in } \\
\text { Ethanol }\end{array}$ & $\begin{array}{l}\text { Insoluble } \\
\text { in ethanol }\end{array}$ & $\begin{array}{l}\text { Soluble } \\
\text { in } \\
\text { acetone }\end{array}$ & $\begin{array}{l}\text { Insoluble } \\
\text { in } \\
\text { acetone }\end{array}$ \\
\hline Myristoleic acid, C14:1 & 0.15 & 0.99 & 0.02 & 1.32 & 1.59 \\
Palmitoleic acid, C16:1 & 0.80 & 1.64 & 0.53 & 1.97 & 2.24 \\
Cis-10-Heptadekanoat & 1.00 & 1.04 & 0.07 & 1.37 & 1.64 \\
Elaidic acid, C18:1n9t & 0.23 & 1.07 & 0.10 & 1.40 & 1.67 \\
Oleic acid, C18:1n9c & 19.64 & 21.31 & 16.34 & $2 ., 63$ & 21.91 \\
Cis-11-Eikosenoat acid, & 0.65 & 1.49 & 0.38 & 1.82 & 2.09 \\
C20:1 & 0.16 & 1.02 & 0.03 & 1.33 & 1.61 \\
Erucat acid, C22:1n9 & 22.63 & 28.56 & 17.47 & 30.84 & 32.75 \\
\hline Mono Unsaturated Fatty & & & & & \\
Acid Total & & & & & \\
\hline
\end{tabular}

Table 2 shows that in each of the fractions can be detected as many as seven types of monounsaturated fatty acids to total monounsaturated fatty acids $17.47 \%-32.75 \%$. The highest fatty acid was oleic acid, which was the crude phospholipid $19.64 \%$, ethanol soluble phospholipids $21.31 \%$, phospholipids insoluble ethanol $16.34 \%$, acetone insoluble phospholipids $21.63 \%$, and phospholipids insoluble acetone $21.91 \%$.

Ethanol soluble fraction had levels of monounsaturated fatty acids (oleic and palmitoleic) higher than the ethanol insoluble fraction. Acetone is a solvent semipolar nature so that dilution with acetone produce levels of unsaturated fatty acids were almost equally between fractions soluble and insoluble acetone. Differences in the fatty acid composition is affected by the solvent. The fatty acid have a single double bond tend to be polar so that more soluble in ethanol.

The fatty acids dominate for phosphatidylinositol (PI), phosphatidyl ethanolamine (PE), and phosphatidylcholine (PC) was oleic acid [8, 11-12]. Fractionation was intended to get phospholipid fractions desired. The soluble fraction of ethanol was expected to produce fractions with the ratio of $\mathrm{PC} / \mathrm{PE}$ was the proper height for oil in water emulsion, while the insoluble fraction of ethanol yield ratio of PC/PE low suitable for water-in-oil emulsion. Rao [3] reported the lipid classes and fatty acid composition of eggs from the Atlantic halibut (Hippoglossus hippoglossus) were studied. The phospholipid fraction contained 62\% PC and $7 \%$ PE with high concentration of n-3 PUFA such as EPA and DHA.

\subsection{Polyunsaturated Fatty Acid (PUFA)}

Type of polyunsaturated fatty acid (Poly Unsaturated Fatty Acid / PUFA) contained in each fraction there are 11 types. For more details, type and amount of polyunsaturated fatty acid in fatty fish each can be seen in Table 3.

In Table 3 shown that the total of polyunsaturated fatty acid was $13.24 \%-22.43 \%$. The highest fatty acid was linoleic acid, which was the crude phospholipid $10.14 \%$, ethanol soluble phospholipid $10.20 \%$, ethanol insoluble phospholipid $9.41 \%$, acetone insoluble phospholipid $9.43 \%$, and phospholipid insoluble acetone $10.99 \%$.

Ethanol soluble fraction had level of polyunsaturated fatty acid was higher than ethanol insoluble fraction. Ethanol was a polar solvent that was able to extract the fatty acids which its polarity level same with solvent. While acetone was a semipolar solvent that produce level of unsaturated fatty acid were almost equally between acetone soluble and 
acetone insoluble fractions. In essence of a material to be easily dissolved in solvent with the same of polarity, because of fat polarities was different so there was no general solvent for all types of fat [13]. Therefore necessary fish oil extraction process in accordance with needs. These results indicate that the soluble fraction of ethanol can increase the concentration of omega-3.

Rao et al., [14] reported EPA and DHA in the phospholipid fractions were 2.0, 7.9\% in catla and 0.3 and $6.3 \%$ in mrigal respectively. Polyunsaturated fatty acids (EPA and DHA) were found to be more concentrated in the phospholipid fractions. EPA was found in smaller amounts while DHA was observed in significant amounts. The concentration of EPA and DHA in significant amounts in the phospholipid fraction was also observed in other roe lipids studied earlier. The fish roes of rohu and murrel showed the presence of eicosapentaenoic acid (20:5, EPA) to an extent of 1.1 and $1.0 \%$ and docosahexaenoic acid (22:6, DHA) to an extent of 14.1 and $6.8 \%$ respectively in the phospholipid fraction.

Table 3. Poly Unsaturated Fatty Acids Composition Phospholipid Fraction

\begin{tabular}{|c|c|c|c|c|c|}
\hline \multirow[b]{2}{*}{ Fatty acid type } & \multicolumn{5}{|c|}{ Amount (\%) } \\
\hline & $\begin{array}{l}\text { Crude } \\
\text { Fosfolipid }\end{array}$ & $\begin{array}{l}\text { Soluble } \\
\text { in ethanol }\end{array}$ & $\begin{array}{l}\text { Insoluble in } \\
\text { ethanol }\end{array}$ & $\begin{array}{l}\text { Soluble in } \\
\text { aceton }\end{array}$ & $\begin{array}{l}\text { Insoluble in } \\
\text { Aceton }\end{array}$ \\
\hline $\begin{array}{l}\text { Linolelaidat asid, } \\
\text { C18:2n9t }\end{array}$ & 0.70 & 0.86 & 0.02 & 0.73 & 0.80 \\
\hline $\begin{array}{l}\text { Linoleic, } \\
\text { C18:2n6c }\end{array}$ & 10.14 & 10.20 & 9.41 & 9.43 & 10.99 \\
\hline $\begin{array}{l}\text { G-Linolenic acid, } \\
\text { C18:3n6 }\end{array}$ & 1.12 & 1.23 & 0.39 & 1.10 & 1.17 \\
\hline $\begin{array}{l}\text { Linolenic acid, } \\
\text { C18:3n3 }\end{array}$ & 1.18 & 1.29 & 0.45 & 1.16 & 1.23 \\
\hline $\begin{array}{l}\text { Cis-11,14- } \\
\text { Eikosedienoat } \\
\text { acid, C20:2 }\end{array}$ & 1.16 & 1.27 & 0.43 & 1.14 & 1.21 \\
\hline $\begin{array}{l}\text { Cis- } 8,11,14- \\
\text { Eikosetrienoat } \\
\text { acid. C20:3n6 }\end{array}$ & 1.44 & 1.55 & 0.71 & 1.42 & 1.49 \\
\hline $\begin{array}{l}\text { Cis-11,14,17- } \\
\text { Eikosetrienoat } \\
\text { acid, C20:3n3 }\end{array}$ & 0.77 & 0.88 & 0.04 & 0.75 & 0.82 \\
\hline $\begin{array}{l}\text { Arachidonic } \\
\text { acid,C20:4n6 }\end{array}$ & 1.35 & 1.46 & 0.62 & 1.33 & 1.43 \\
\hline $\begin{array}{l}\text { Cis-13,16- } \\
\text { Dokosadienoat } \\
\text { acid. C22:2 }\end{array}$ & 0.75 & 0.86 & 0.02 & 0.74 & 0.80 \\
\hline $\begin{array}{l}\text { Cis-5, } 8,11,14,17- \\
\text { Eikosapentaenoat } \\
\text { acid, C20:5n3 }\end{array}$ & 1.01 & 1.12 & 0.28 & 1.72 & 1.26 \\
\hline $\begin{array}{l}\text { Cis- } \\
4,7,10,13,16,19- \\
\text { Dokosaheksaenoat } \\
\text { acid, C22:6n3 }\end{array}$ & 1.60 & 1.71 & 0.87 & 158 & 1.65 \\
\hline $\begin{array}{l}\text { Poly Unsaturated } \\
\text { acid total }\end{array}$ & 21.22 & 22.43 & 13.24 & 21.10 & 21.85 \\
\hline
\end{tabular}


The fatty acid profile of total lipids showed that the saturated fatty acids were found to an extent of 52.0 and $52.8 \%$ with major fatty acid being hexadecanoic acid to an extent of 34.7 and $37.5 \%$ in catla and mrigal eggs respectively. However, the saturated octadecanoic $(13.8,12.3 \%)$ and monounsaturated octadecenoic acid $(22.9,17.9 \%)$ were also present in considerable quantities. The octadecadienoic acid and octadecatrienoic acids were 3.3, 2.0\% and 2.9, 6.0\% in catla and mrigal lipids respectively. EPA (20:5) and DHA (22:6) were found to be $2.0,6.9 \%$ and $0.5,8.9 \%$ in catla and mrigal roe lipids respectively [3].

\section{Conclusion}

The research concluded that the highest of saturated fatty acid level was found in waste of jambal siam fish processing was palmitic acid which was suspected dominates the formation phospatidylgliserol (PG), phosphatidic acid (PA), and cardiolipin (DPG). The highest of unsaturated fatty acid level was oleic acid which allegedly dominate the formation of phosphatidylinositol (PI), phosphatidyl ethanolamine (PE), and phosphatidylcholine (PC).

Ethanol was a polar solvent that produced the fraction of unsaturated fatty acid of soluble ethanol higher than insoluble ethanol. While acetone was a solvent that was semipolar so that dilution with acetone produced level of unsaturated fatty acid were almost equally between aceton soluble fraction and acetone insoluble fraction.

\section{References}

[1] Departement of Fisheries and Marine Riau Province, "The Annual Report Freshwater Fish Culture", Pekanbaru, (2009).

[2] M. G. Tyagi, "Analysis of Phosfolipids Using the High Performance Liquid Chromatography Technique", International Journal of Current Research in Biosciences and Plant Biology., vol. 3, no. 4, (2016), pp. 28-31.

[3] P. P. G. Rao, K. Balaswany, R. Narsing, T. Jyothirmayi, M. S. L. Karuna and R. B. N. Prasad, "Lipid classes, fatty acid and phospholipid compostion of roe lipids from Catla catla and Cirrhinus mrigala", International Food Research Journal., vol. 20, no. 1, (2013), pp. 275-279.

[4] W. Gładkowski, G. Kiełbowicz, A. Chojnacka, T. G, M., Trziszka, Z. Dobrzański and C. Wawrzeńczyk, "Fatty Acid Composition of Egg Yolk Phospholipids Fractions Following Feed Supplementation of Lohmann Brown Hens with Humic-Fat Preparations", Food Chemistry Journal., vol. 126, (2011), pp. 1013-1018.

[5] M. Ilza and Y. Siregar, "Socializing the Addition of Jambal Siam (Pangasius hypophtalmus) Fish Stomach Oil and Kerapu (Cromileptes sp) Fish Oil in Baby Porridge for Satisfy Omega 3 and Omega 6 Standard”, Jurnal Pengolahan Hasil Perikanan Indonesia., vol. 18, no. 3, (2015), pp. 262-273.

[6] Y. Sato, T. Nakamura, K. Aoshima and Y. Oda, "Quantitative and Wide Ranging Profiling of Phospholipids in Human Plasma by Two Dimensional Liquid Chromatography/Mass Spectrometry", Anal. Chem., vol. 82, (2010), pp. 9858-9864.

[7] Y. Y. Zhao, Y. Xiong and J. M. Curtis, "Measurement of Phospholipids by Hydrophilic Interaction Liquid Chromatography Coupled to Tandem Mass Spectrometry: the Determination of Choline Containing Compounds in Foods", Journal of Chromatography., A, 1218, (2011), pp. 5470-5479.

[8] T. Estiasih, K. Ahmadi, F. C. Nisa and A. D. Khulug, "Phospholipids Extraction and Fractionation of Palm Oil Waste Processing”, J. Tehnol. and Food Industry, vol. 21, no. 2, (2010), pp. 151-159.

[9] AOAC, "Official Methods of Analysis", $15^{\text {th }}$ ed, Virginia, USA, vol. 2, (1990).

[10] P. W. Park and R. W. Goins, "In Situ Preparation of Fatty Acids Methyl Ester for Analysis of Fatty Acids Composition", Journal of Food Science., vol. 59, (1994), pp. 1262-1266.

[11] T. Estiasih, K. Ahmadi, W.B. Sunarharum and R.A. Destryana, "Safonifikasi dan ekstraksi satu tahap untuk ekstraksi minyak tinggi linoleat dan linolenat dari kedelai varietas lokal", Agritechnology Journal., vol. 31, (2011), pp. 36-45.

[12] T. Estiasih, M. Nur, J.M. Maligan and S. Maulana, "Sintesis fosfolipid mengandung asam lemak omega 3 dari fosfolipid kedelai dan minyak kaya asam lemak omega 3 dari hasil samping pengalengan tuna", Agritechnology Journal., vol. 32, (2012), pp. 284-292.

[13] N.R. Rodguez, S. Beltran, I. Jaime, S.M. de Diego, M.T. Sanz, J.R. Carbalido, "Production of Omega 3 Polyunsaturated Fatty Acid Concentrates: A Review, Innovative Food Science \& Emerging Technologies., vol. 11, no. 1, (2010), pp. 1-12. 
[14] P.P.G. Rao, T. Jyothirmayi, M.S.L. Karuna R.B.N. Prasad, "Studies on Lipid Profiles and Fatty Acid Composition of Roe from Rohu (Labeo rohita) and Murrel (Channa striatus). Journal of Oleo Science., vol. 59, (2010), pp. 515-519

\section{Authors}

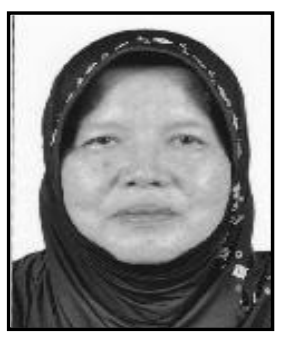

Mirna Ilza obtained her Bachelor Degree (Ir) from Andalas University, Master Degree (M.S) degree from Padjadjaran University, and Ph.D degree from Andalas University, Indonesia. She is a professor at Department of Fishery Product Processing Faculty of Fisheries and Marine Universitas Riau Indonesia.

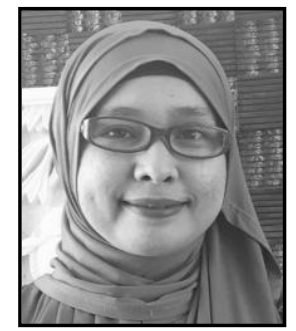

Dian Iriani obtained her Master degree (MP) from Brawijaya University in Malang East Java Indonesia and (M.Sc) degree from Burapha University Thailand. She is a lecturer in Department of Fishery Product Processing Faculty of Fisheries and Marine Universitas Riau Indonesia. 
International Journal of Bio-Science and Bio-Technology Vol.9, No.2 (2017) 